7. Erasmus JJ, McAdams HP, Rossi S, Kelly MJ. Interventional chest radiology: percutaneous management of intrapulmonary air and fluid collections. Radiol Clin North Am. 2000;38:385-93.

8. Kaplan LJ, Trooskin SZ, Santora TA, Weiss JP. Percutaneous drainage of recurrent pneumothoraces and pneumatoceles. J Trauma. 1996;41:1069-72.

9. Chon KS, van Sonnenberg E, D'Agostino HB, O'Laoide RM, Colt HG, Hart E. CT-guided catheter drainage of loculated thoracic air collections in mechanically ventilated patients with acute respiratory distress syndrome. Am J Roentgenol. 1999;173:1343-50.

10. Santambrogio L, Nosotti M, Pavoni G, Harte M, Pietogrande MC. Pneumatocele complicated by fungal lung abscess in Job's syndrome. Scand Cardiovasc J. 1997;31:177-9.

11. Wu MH, Tseng YL, Lai WW. Surgical treatment of pediatric lung abscess. Pediatr Surg Int. 1997;12:293-5.

\title{
Solitary squamous papillomas of the bronchus: A case report and literature review
}

\author{
C. J. McNamee, MD, ${ }^{a}$ D. Lien, MD, ${ }^{\mathrm{b}}$ L. Puttagunta, MD, ${ }^{\mathrm{b}}$ and A. Alan Conlan, MD, \\ Worcester, Mass, and Edmonton, Alberta, Canada
}

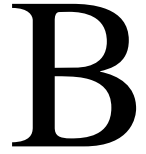

ronchial papillomas are rare tumors that account for $0.38 \%$ of all lung tumors and $7 \%$ to $8 \%$ of all benign lung tumors. ${ }^{1,2}$ Adult bronchial papillomas can be classified according to the number of lesions, location, and histologic type. Multiple papillomas within the trachea or bronchus could represent either recurrent respiratory papillomatosis or inflammatory polyps. ${ }^{3}$ Solitary papillomas of the bronchus can be divided into three groups: squamous cell papilloma, glandular papillomas, and mixed squamous cell and glandular papillomas. ${ }^{4}$ There is a strong association between human papillomavirus (HPV) infection and two of the aforementioned pathologic states, recurrent respiratory papillomatosis and solitary papillomas of the bronchus..$^{2,5-7}$ In this report we describe a case of solitary squamous papilloma of the bronchus and review the pathobiology associated with the transformation of epithelial cells by HPV.

\section{Clinical Summary}

A 23-year-old nonsmoking woman came to the hospital with a small apical left pneumothorax. Her relevant history revealed multiple left-sided pneumothoraces in the past, for which 3 years previously she had undergone an open pleurectomy at an outside hospital. A bronchoscopy on this admission revealed an obstructing tumor in the left main bronchus, $2 \mathrm{~cm}$ from the carina, which bled copiously when touched by biopsy forceps. The pediatric bronchoscope could not pass the obstruction, and a computed tomographic scan revealed a mass in the bronchus extending to the

From the Division of Cardiothoracic Surgery, Department of Surgery, University of Massachusetts Medical School, Worcester, Mass, ${ }^{\mathrm{a}}$ and the Department of Medicine and Pathology, University of Alberta, Edmonton, Alberta, Canada. ${ }^{\mathrm{b}}$

Received for publication Dec 26, 2002; accepted for publication Feb 14, 2003.

Address for reprints: C. J. McNamee, MD, 67 Belmont St, Worcester, MA 01605 (E-mail: mcnameec@ummhc.org).

J Thorac Cardiovasc Surg 2003;126:861-3

Copyright (C) 2003 by The American Association for Thoracic Surgery

$0022-5223 / 2003 \$ 30.00+0$

doi:10.1016/S0022-5223(03)00369-6

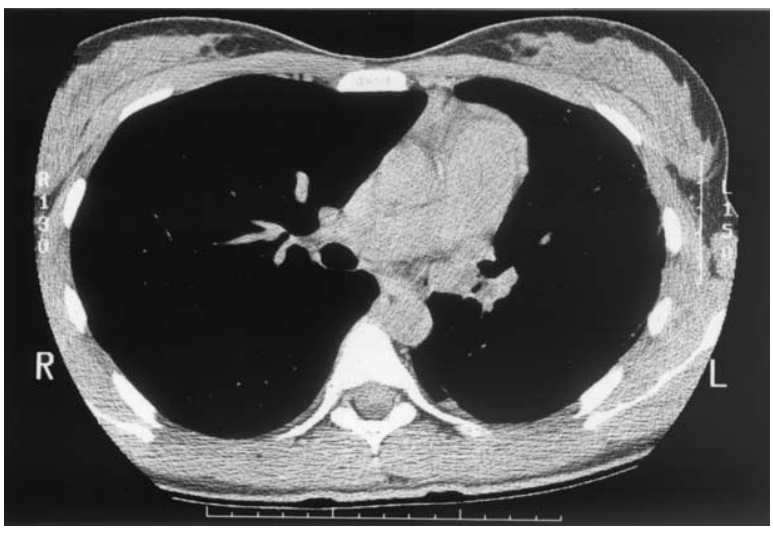

Figure 1. Computed tomographic scan of the chest demonstrating the tumor occluding the left main bronchus with only marginal ventilation of the left lower lobe.

left lower lobe, with complete collapse of the left upper lobe (Figure 1). A bronchoscopically obtained biopsy sample suggested a squamous papilloma of the bronchus. Endoscopic removal or laser therapy was not considered because of the risk of endobronchial hemorrhage and collateral damage to the airway. Surgical resection of the tumor was conducted by left thoracotomy through the previous incision. This approach was preferred to sternotomy for exposure of the proximal main bronchus up to the carina as well as because it allowed us the possibility of pneumonectomy and ex vivo tumor dissection with reimplantation of the lower lobe if necessary. Fortunately, only an extended sleeve resection of the left upper lobe was required to remove the tumor with negative margins. Final pathologic examination confirmed a squamous papilloma of the left main bronchus (Figure 2); DNA examination was negative for HPV 6, 11, 16, 18, 25, 31, and 33 serotypes. The patient has had no evidence of symptomatic recurrence at 36 months of follow-up.

\section{Discussion}

Solitary squamous papilloma of the bronchus is a rare tumor, with between 27 and 31 cases in the English-language literature re- 

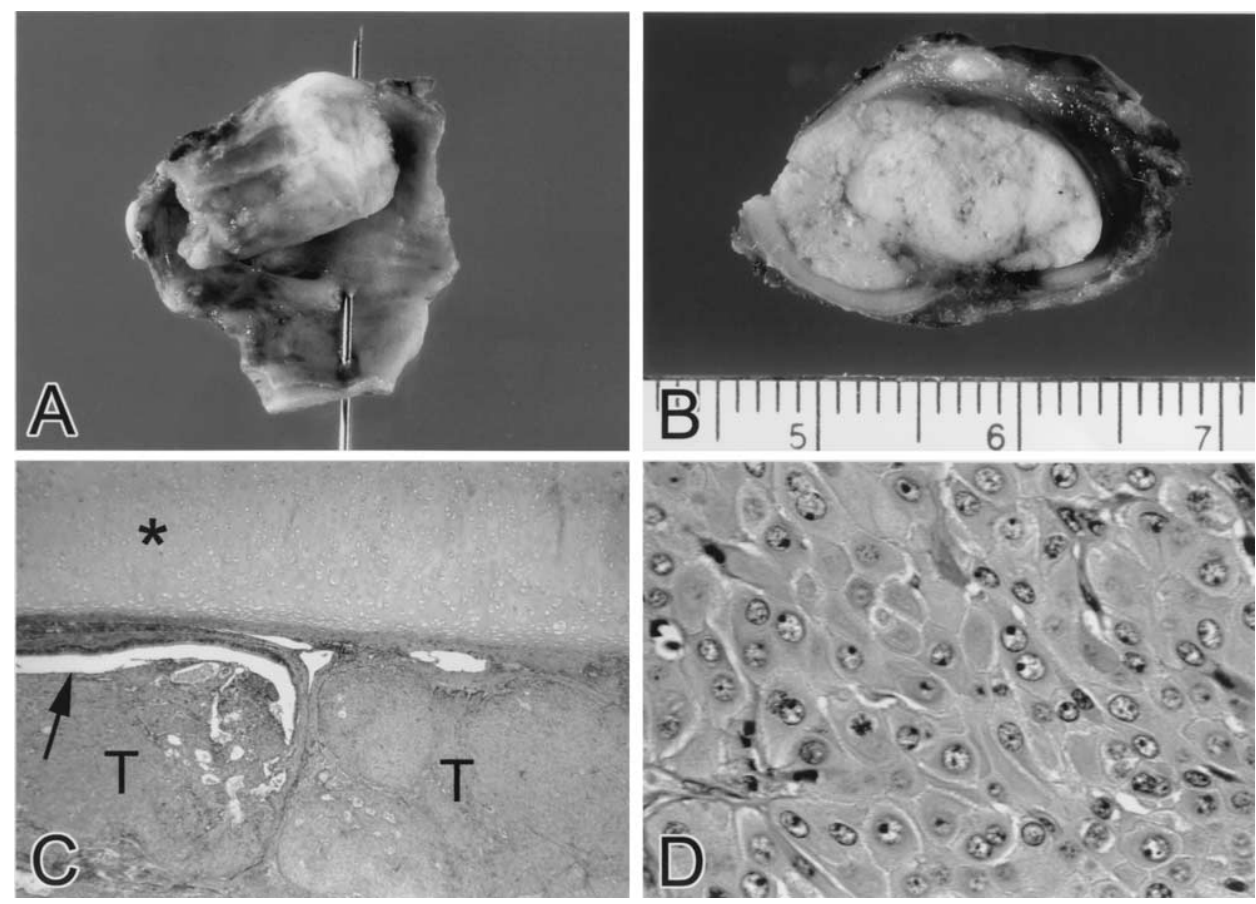

Figure 2. Final pathologic examination of squamous papilloma of left main bronchus. A, Gross photograph of endobronchial tumor with proximal bronchus wall pinned open. B, Cross-sectional photograph of endobronchial tumor (scale in millimeters). C, Microscopic section of tumor (T) in cross-section. Asterisk indicates cartilaginous wall; arrow points to narrow residual airway to left lower lobe (original magnification $\times 25$, hematoxylin and eosin stain). D, High-power microscopic appearance of tumor showing sheets of squamous cells with intercellular bridges (original magnification $\times 400$, hematoxylin and eosin stain).

ported to $1998 . .^{4,7}$ Since 1998 there have only been 2 further reported cases of solitary squamous papilloma of the bronchus. ${ }^{8,9}$ The minor variability in the number of reportable cases depends on the degree to which malignant degeneration of squamous papillomas is accepted, as opposed to a squamous carcinoma exhibiting a papilloform surface. ${ }^{4,7}$

There is strong evidence in the literature supporting infection of these papillomas by HPV. 2,4,7,9,10, 11 The two largest recent series of these tumors clearly show that one of the serotypes HPV 6,11 , $16,18,31,33$, or 35 will infect $71 \%$ to $100 \%$ of these papillomas, ${ }^{4,7}$ and the serotype may predict the malignant potential of the papilloma. $^{7}$ The possibilities for acquiring the virus are as a latent birth infection with delayed presentation or as an acquired infection from infected secretions. ${ }^{5,12}$ It is strongly suspected that HPV can initiate papilloma formation as in recurrent respiratory papillomatosis, particularly because there is effective treatment of the papillomas with antiviral therapy by either topical ${ }^{13}$ or systemic $^{14,15}$ administration.

There is a strong but not absolute association between solitary squamous cell papillomas of the bronchus and HPV identification either by viral cytopathic effect or by in situ hybridization. ${ }^{4,7} \mathrm{HPV}$ infections involve capsid uncoating of the double-stranded viral DNA in the nucleus of keratinocytes to which HPV has a special tropism. Viral replication can have three outcomes within the nucleus of the epithelial cell. Synchronous but separate replication in tandem with the host DNA may cause latent infection of morphologically normal cells. Productive infection involves increased replication of viral DNA proteins out of sequence with host DNA replication cycle. This increased viral production causes morphologic changes in the host cells thought to be associated with low-grade dysplasia. Finally, insinuation of viral DNA into host DNA is thought to create high risk of malignant transformation of host cells. In this situation the HPV circular DNA constantly breaks at the site of two repressors (E1, E2) of cell cycle activity. This allows overexpression of HPV E6 and E7 proteins now ensconced in one of the host DNA strands. Increased E6 protein production interferes with negative cell cycle regulator P53, whereas increased E7 production interferes with retinoblastoma protein, allowing for increased cell proliferation and later malignant transformation. ${ }^{5,6}$

The malignant potential of squamous papillomas from the literature ranges from $8 \%$ to $40 \%^{7,8}$; moreover the chance of malignancy elsewhere in the lung is $13 \%$, but it may occur at multiple sites. ${ }^{8}$ Furthermore there is evidence in the literature suggesting malignant conversion of solitary squamous papillomas $^{11}$ and malignant degeneration of sites where solitary squamous papillomas have been endoscopically removed. ${ }^{2,7,16}$ There is also one report of endoscopic removal of a benign papilloma leaving behind an underlying malignancy. ${ }^{8}$ The risk of malignant conversion of these papillomas is increased with smoking, ${ }^{8,17}$ age greater than 40 years, and infection with HPV serotype 16 or $18 .^{7}$ HPV serotypes 6 and 11 are considered to have a weaker malig- 
nant potential, ${ }^{7}$ although type 11 at least has been associated with malignant degeneration of a solitary squamous papilloma. ${ }^{11}$

The endoscopic option for removal of solitary squamous papillomas is excision by snare electrocautery or by laser. ${ }^{8,16,2}$ The rational for endoscopic excision is the possibility of involvement by cancer of other sites in the tracheobronchial tree and the need for lung-sparing procedures. Endoscopic destruction by laser may prevent full pathologic examination of the whole papilloma, which may have had evidence of carcinoma at the base of the tumor. ${ }^{7,16}$ There is also the possibility of operator infection by vaporized HPV papillomas. ${ }^{18,19}$

Snare electrocautery allows retrieval of the papilloma for a more complete pathologic examination. However, even this method can conceal an underlying malignancy ${ }^{8}$ or falsely suggest a squamous cell carcinoma. ${ }^{4}$

Resectional surgery with lung-sparing techniques is the most common treatment method, because any occult malignancy is removed and recurrence is thus avoided. ${ }^{8}$ Treatment with antiviral therapy or interferon alfa, as is done with recurrent respiratory papillomatosis, has no proven role in this condition.

Ultimately the best treatment depends on the medical condition of the patient. However, it is safe to suggest that hemorrhagic lesions or tumors with atypia or dysplasia in HPV-seronegative patients may be best treated by thoracotomy and resection if feasible. If endoscopic excision is used, then routine surveillance should be performed to prevent recurrence or malignancy, as should be the case with all squamous papillomas with HPV serotype 16 or 18 and possibly those with HPV 11 serotype.

\section{References}

1. Hurt R. Benign tumors of the bronchus and trachea, 1951-1981. Ann $R$ Coll Surg Engl. 1984;66:22-6.

2. Popper HH, Wirnsberger G, Juttner-Smolle FM, Pongratz MG, Sommersgutter M. The predictive value of human papilloma virus (HPV) typing in the prognosis of bronchial squamous papillomas. Histopathology. 1992;21:323-30.

3. Drennan JM, Douglas AC. Solitary papilloma of a bronchus. J Clin Pathol. 1965;18:401-2.

4. Flieder DB, Koss MN, Nicholson A, Sesterhenn IA, Petras RE, Travis WD. Solitary pulmonary papillomas in adults. A clinicopathologic and in situ hybridization study of 14 cases combined with 27 cases in the literature. Am J Surg Pathol. 1998;22:1328-42.
5. Cheah PL, Looi LM. Biology and pathological associations of the human papillomaviruses: a review. Malays J Pathol. 1998;20:1-10.

6. Sisk EA, Robertson ES. Clinical implications of human papillomavirus. Front Biosci. 2002;7:619-26.

7. Popper HH, el-Shabrawi Y, Wockel W, Hofler G, Kenner L, JuttnerSmolle FM, et al. Prognostic importance of human papilloma virus typing in squamous cell papilloma of the bronchus: comparison of in situ hybridization and the polymerase chain reaction. Hum Pathol. 1994;25:1191-7.

8. Inoue $\mathrm{Y}$, Oka M, Ishii H, Kimino K, Kishikawa M, Ito M, et al. A solitary bronchial papilloma with malignant changes. Intern Med. 2001;40:56-60.

9. Kawaguchi T, Matumura A, Iuchi K, Yamamoto S, Inoue Y, Sunami $\mathrm{T}$, et al. Solitary squamous papilloma of the bronchus associated with human papillomavirus type 11. Intern Med. 1999;38:817-9.

10. Trillo A, Guha A. Solitary condylomatous papilloma of the bronchus. Arch Pathol Lab Med. 1988;112:731-3.

11. Bejui-Thivolet F, Chardonnet Y, Patricot LM. Human papillomavirus type 11 DNA in papillary squamous cell lung carcinoma. Virchows Arch A Pathol Anat. 1990;417:457-61.

12. Katial RK, Ranlatt R, Whitlock WL. Human papilloma virus associated with solitary squamous papilloma associated with bronchiectasis and bronchial stenosis. Chest. 1994;106:1887-9.

13. Bielamowicz S, Villagomez V, Stager SV, Wilson WR. Intralesional cidofovir therapy for laryngeal papilloma in an adult cohort. Laryngoscope. 2002;12:696-9.

14. Armbruster C, Kreuzer A, Vorbach H, Huber M, Armbruster C. Successful treatment of severe respiratory papillomatosis with intravenous cidofovir and interferon alpha-2b. Eur Respir J. 2001;17: 830-1.

15. Dancey DR, Chamberlain DW, Krajden M, Palefsky J, Alberti PW, Downey GP. Successful treatment of juvenile laryngeal papillomatosis-related multicystic lung disease with cidofovir: case report and review of the literature. Chest. 2000;118:1210-4.

16. Miura H, Tsuchida T, Kawate N, Konaka C, Kato H, Ebihara Y. Asymptomatic solitary papilloma of the bronchus: review of occurrence in Japan. Eur Respir J. 1993;6:1070-3.

17. Roviaro GC, Varoli F, Pagnini CA. Is the solitary papilloma of the bronchus always a benign tumor? ORL J Otorhinolaryngol Relat Spec. 1981;43:301-8.

18. Hallmo P, Naess O. Laryngeal papillomatosis with human papillomavirus DNA contracted by a laser surgeon. Eur Arch Otorhinolaryngol. 1991;248:425-7.

19. Bergbrant IM, Samuelsson L, Olofsson S, Jonassen F, Ricksten A. Polymerase chain reaction for monitoring human papillomavirus contamination of medical personnel during treatment of genital warts with $\mathrm{CO}_{2}$ laser and electrocoagulation. Acta Derm Venereol. 1994;74:393-5. 